\title{
Second-hand smoke and indoor air quality in public places in Gaza city
}

I. Abuelaish, ${ }^{\text {A A.B. Seidenberg, }}{ }^{2}$ R.D. Kennedy ${ }^{2,3}$ and V.W. Rees ${ }^{2}$

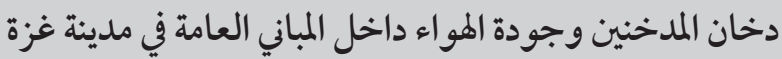

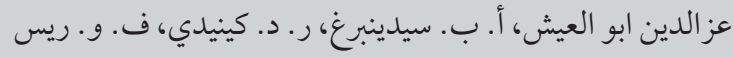

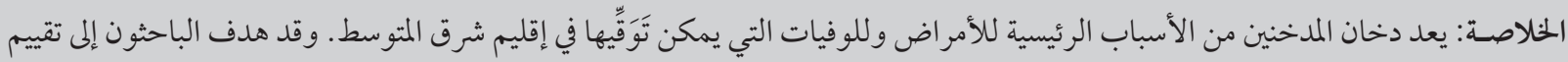

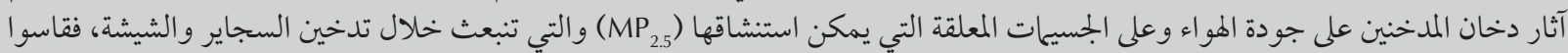

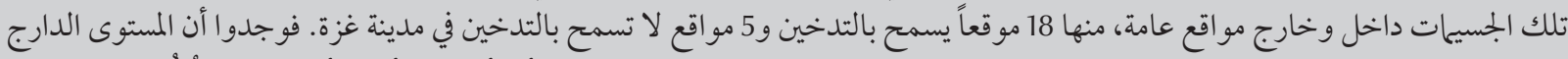

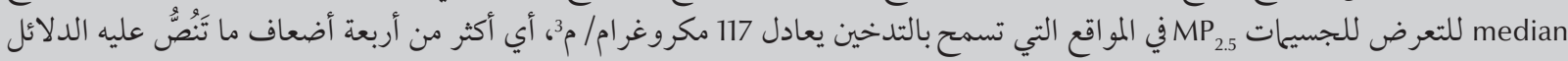

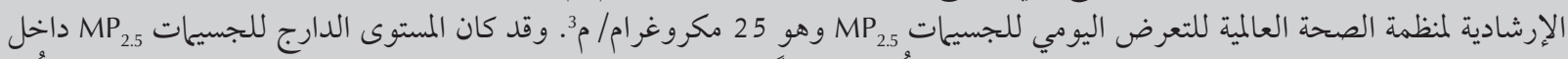

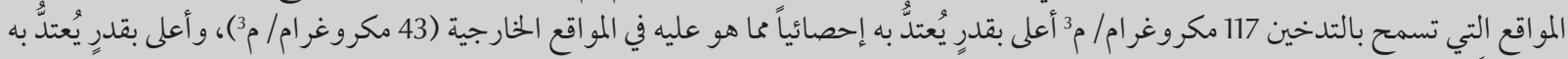

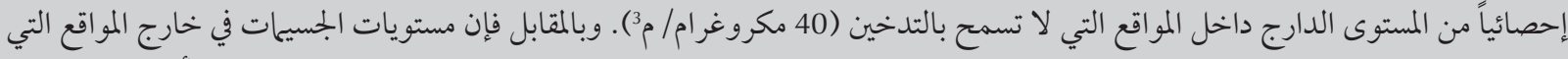

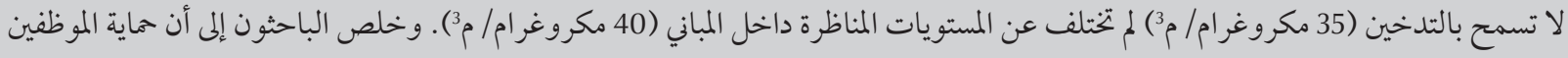

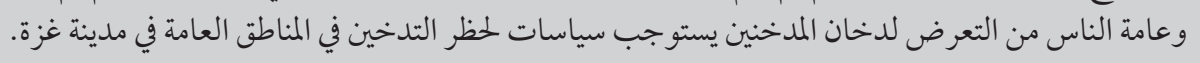

ABSTRACT Second-hand smoke is a major cause of preventable disease and death in the Eastern Mediterranean Region. To assess how second-hand smoke impacts air quality, respirable suspended particles $\left(\mathrm{PM}_{2.5}\right)$, which are emitted during cigarette and waterpipe smoking, were measured inside and outside of 18 smoking and 5 nonsmoking public venues in Gaza city. Median $\mathrm{PM}_{2.5}$ level inside the smoking venues was $117 \mu \mathrm{g} / \mathrm{m}^{3}$, which exceeds the WHO guidelines for daily $\mathrm{PM}_{2.5}$ exposure $\left(25 \mu \mathrm{g} / \mathrm{m}^{3}\right)$ by more than 4 -fold. The median level inside the smoking venues $\left(117 \mu \mathrm{g} / \mathrm{m}^{3}\right)$ was significantly higher than outside the venues $\left(43 \mu \mathrm{g} / \mathrm{m}^{3}\right)$, and significantly higher than the median level inside non-smoking venues $\left(40 \mu \mathrm{g} / \mathrm{m}^{3}\right)$. By contrast, particulate levels outside non-smoking venues $\left(35 \mu \mathrm{g} / \mathrm{m}^{3}\right)$ did not differ from the corresponding levels inside $\left(40 \mu \mathrm{g} / \mathrm{m}^{3}\right)$. To protect employees and the public from second-hand smoke exposure, policies prohibiting smoking in public places are needed in Gaza city.

\section{Tabagisme passif et qualité de l'air intérieur dans des lieux publics de la ville de Gaza}

RÉSUMÉ Le tabagisme passif est une cause majeure de morbi-mortalité évitable dans la Région de la Méditerranée orientale. Pour évaluer l'impact du tabagisme passif sur la qualité de l'air, les particules respirables en suspension $\left(\mathrm{PM}_{2,5}\right)$ émises pendant la consommation de cigarettes et de pipes à eau ont été mesurées à l'intérieur et à l'extérieur de 18 lieux publics fumeurs et 5 lieux publics non-fumeurs de la ville de Gaza. Le taux de $\mathrm{PM}_{2,5}$ moyen à l'intérieur des lieux fumeurs était de $117 \mu \mathrm{g} / \mathrm{m}^{3}$, un taux plus de quatre fois supérieur aux recommandations de l'Organisation mondiale de la Santé pour l'exposition quotidienne aux particules fines $\left(25 \mu \mathrm{g} / \mathrm{m}^{3}\right)$. Le taux intérieur médian des lieux fumeurs $\left(117 \mu \mathrm{g} / \mathrm{m}^{3}\right)$ était nettement supérieur au taux extérieur $\left(43 \mu \mathrm{g} / \mathrm{m}^{3}\right)$ et significativement supérieur au taux intérieur médian des lieux non-fumeurs $\left(40 \mu \mathrm{g} / \mathrm{m}^{3}\right)$. En revanche, les taux de particules à l'extérieur des lieux non-fumeurs $\left(35 \mu \mathrm{g} / \mathrm{m}^{3}\right)$ et à l'intérieur de ces mêmes lieux $\left(40 \mu \mathrm{g} / \mathrm{m}^{3}\right)$ étaient similaires. Afin de protéger les employés et le public de l'exposition au tabagisme passif, des politiques interdisant le tabagisme dans les lieux publics sont nécessaires dans la ville de Gaza.

${ }^{7}$ Global Health Division, Dalla Lana School of Public Health, University of Toronto, Toronto, Ontario, Canada (Correspondence to V.W. Rees: vrees@hsph.harvard.edu).

${ }^{2}$ Center for Global Tobacco Control, Department of Social and Behavioral Sciences, Harvard School of Public Health, Boston, Massachusetts, United States of America.

${ }^{3}$ Propel Centre for Population Health Impact, University of Waterloo, Waterloo, Ontario, Canada

Received: 18/12/11; accepted: 17/04/12 


\section{Introduction}

Exposure to second-hand smoke(SHS) is a major cause of morbidity and premature mortality among non-smokers [1]. More than 250 compounds known to be carcinogenic or toxic have been identified in SHS, and epidemiological data has identified SHS exposure to be associated with numerous diseases, including lung cancer and cardiovascular disease in adults, and otitis media, asthma severity and sudden infant death syndrome in children $[1,2]$.

In the Eastern Mediterranean Region (EMR), exposure to SHS is an important public health burden, especially among children. Recent analysis of the Global Youth Tobacco Survey (2000-06) found that $60.9 \%$ of youth from the EMR reported exposure to SHS, compared with $54.2 \%$ of youth worldwide [3]. It has been estimated that SHS exposure contributed to the deaths (lower respiratory infections, asthma and otitis media) of some 32000 children in the EMR in 2004 [4]. Furthermore, studies conducted in Gaza have found associations between low birth weight and infant mortality and SHS exposure $[5,6]$. A previous survey revealed that the prevalence of smoking in Palestine was higher among male than female adults ( $40.7 \%$ versus $3.2 \%$ ), which is consistent with other countries in the Region [7]. Such a high rate of smoking among adult males may result in a large number of women and children exposed to SHS in the home, as well as workers in hospitality venues.

To protect workers and the public from SHS exposure, countries have developed, enacted and enforced comprehensive smoke-free policies, which prohibit smoking in enclosed public venues (e.g. restaurants and cafes). A handful of countries in the EMR have passed comprehensive smoke-free legislation, including the Syrian Arab Republic [8], Jordan [9] and Lebanon [10]; however, enforcement of these laws is a challenge that undermines their full potential [11].

The measurement of indoor fine particulate matter of $2.5 \mu \mathrm{m}$ or less $\left(\mathrm{PM}_{2.5}\right)$, a product of both cigarette and waterpipe smoking, is commonly used to quantify the impact SHS has on indoor air quality. Such research has helped to educate the public and policy-makers about the dangers of SHS and has been instrumental in informing smoke-free policies [12]. SHS air quality monitoring has previously been conducted within the EMR and has identified dangerous levels of particulate matter in smoking public venues in Lebanon, Pakistan, Syrian Arab Republic and Tunisia [13-15]. To date, no known research has been conducted on SHS emissions in the Palestinian Authority, where economic and political uncertainty and instability have created unique public health challenges, and where effective preventive health policies are needed.

The purpose of this investigation was to assess how SHS impacts air quality inside a sample of public venues in Gaza city. Air quality in a subset of venues with voluntary non-smoking policies was measured for comparison.

\section{Methods}

\section{Data collection}

A cross-sectional study was conducted to monitor air quality inside a convenience sample of 23 public venues in Gaza city during July and August of 2010 using an established protocol [12]. Venues visited included restaurants, cafés, barber shops, banks and telecommunication centres (used for internet and international phone calls) and all venues were fully enclosed. While smoking was permitted in 18 venues (smoking venues), 5 venues were voluntarily smoke free (nonsmoking venues).

$\mathrm{PM}_{2.5}$ concentrations were measured for a minimum of 30 minutes inside each venue using a personal aerosol monitor (TSI SidePak AM510, TSI Inc.). The device was set to a 1-minute logging interval, which averages the previous 601 -second measurements. Particulate levels were also measured for 5 minutes outside each venue (immediately before indoor measurements) to account for ambient $\mathrm{PM}_{2.5}$.

In addition, the number of cigarette and waterpipe (narghile) smokers inside each venue was counted at 0,15 and 30 minutes. These values were then averaged for each venue. The interior volume of each venue was measured using a sonic measure (Zircon DM S50L).

\section{Data analysis}

Measurements were uploaded using TrakPro, version 4.3.0.4 software, and imported into Microsoft Excel 2007 for data management. A calibration factor of 0.32 was applied to all data, which is appropriate for SHS measurement with the SidePak monitor [13].

For each venue visited, the $\mathrm{PM}_{2.5}$ levels were averaged over the total period of measurement for both inside and outside measurements. Twosample Wilcoxon rank-sum tests were performed to compare particulate levels between the inside and outside measurements, and between the indoor smoking and non-smoking venues. Active smoker density was calculated by dividing the mean number of smokers by venue volume (mean number of smokers $/ 100 \mathrm{~m}^{3}$ ). Spearman correlation was used to assess a potential association between active smoker density and mean $\mathrm{PM}_{2.5}$ level.

\section{Results}

The volume and smoker statistics for each venue visited in Gaza city are shown in Table 1.

The median indoor concentration of $\mathrm{PM}_{2.5}$ for the 18 smoking venues 


\begin{tabular}{|c|c|c|c|c|c|c|c|c|}
\hline \multirow[t]{3}{*}{ Venue } & \multirow[t]{3}{*}{ Venue type } & \multirow{3}{*}{$\begin{array}{l}\text { Smoking } \\
\text { allowed }\end{array}$} & \multicolumn{2}{|c|}{ Mean $\mathrm{PM}_{2.5}$ level } & \multirow{3}{*}{$\begin{array}{c}\text { Venue } \\
\text { volume } \\
\left(\mathrm{m}^{3}\right)\end{array}$} & \multicolumn{2}{|c|}{ Mean no. of smokers } & \multirow{3}{*}{$\begin{array}{l}\text { Active smoker } \\
\text { density }^{\mathrm{a}}\end{array}$} \\
\hline & & & Indoor & Outdoor & & & & \\
\hline & & & $\left(\mu \mathrm{g} / \mathrm{m}^{3}\right)$ & $\left(\mu \mathrm{g} / \mathrm{m}^{3}\right)$ & & Cigarettes & Waterpipe & \\
\hline 1 & Restaurant & Yes & 290 & 30 & 450 & 2.7 & 2.3 & 1.1 \\
\hline 2 & Barber & Yes & 281 & 51 & 126 & 2.3 & 0.0 & 1.9 \\
\hline 3 & Bank & Yes & 270 & 21 & 448 & 4.3 & 0.0 & 1.0 \\
\hline 4 & Café & Yes & 209 & 40 & 123 & 0.3 & 7.7 & 6.5 \\
\hline 5 & Café & Yes & 192 & 69 & 600 & 0.0 & 6.3 & 1.1 \\
\hline 6 & Café & Yes & 140 & 25 & 448 & 1.0 & 5.3 & 1.4 \\
\hline 7 & Barber & Yes & 131 & 45 & 72 & 0.3 & 0.0 & 0.5 \\
\hline 8 & Café & Yes & 127 & 56 & 900 & 1.7 & 13.7 & 1.7 \\
\hline 9 & Barber & Yes & 119 & 39 & 42 & 0.7 & 0.0 & 1.6 \\
\hline 10 & Café & Yes & 114 & 46 & 156 & 0.7 & 0.0 & 0.4 \\
\hline 11 & Café & Yes & 105 & 28 & 327 & 1.3 & 6.3 & 2.3 \\
\hline 12 & Café & Yes & 104 & 42 & 462 & 2.0 & 6.0 & 1.7 \\
\hline 13 & Barber & Yes & 101 & 40 & 126 & 1.7 & 0.0 & 1.3 \\
\hline 14 & Café & Yes & 71 & 43 & 2352 & 1.0 & 11.7 & 0.5 \\
\hline 15 & Café & Yes & 51 & 27 & 1280 & 0.3 & 6.0 & 0.5 \\
\hline 16 & Bank & Yes & 44 & 58 & 210 & 0.3 & 0.0 & 0.2 \\
\hline 17 & Barber & Yes & 43 & 143 & 45 & 0.7 & 0.0 & 1.5 \\
\hline 18 & Café & Yes & 42 & 61 & 420 & 1.0 & 5.0 & 1.4 \\
\hline 19 & Telecom & No & 58 & 35 & 240 & 0.0 & 0.0 & 0.0 \\
\hline 20 & Telecom & No & 43 & 26 & 360 & 0.0 & 0.0 & 0.0 \\
\hline 21 & Telecom & No & 40 & 51 & 336 & 0.0 & 0.0 & 0.0 \\
\hline 22 & Telecom & No & 26 & 54 & 216 & 0.0 & 0.0 & 0.0 \\
\hline 23 & Barber & No & 21 & 22 & 84 & 0.0 & 0.0 & 0.0 \\
\hline
\end{tabular}

${ }^{a}$ Mean no. of smokers $/ 100 \mathrm{~m}^{3}$.

$\left(117 \mu \mathrm{g} / \mathrm{m}^{3}\right.$; range $\left.42-290 \mu \mathrm{g} / \mathrm{m}^{3}\right)$ was significantly higher than for the indoor concentration of the 5 non-smoking venues ( $40 \mu \mathrm{g} / \mathrm{m}^{3}$; range $21-58 \mu \mathrm{g} /$ $\left.\mathrm{m}^{3}\right)(P=0.003)$. Similarly, the median indoor $\mathrm{PM}_{2.5}$ concentration for the 18 smoking venues was significantly higher than the outdoor $\mathrm{PM}_{25}$ concentration for the 18 smoking venues $\left(43 \mu \mathrm{g} / \mathrm{m}^{3}\right.$; range $\left.21-143 \mu \mathrm{g} / \mathrm{m}^{3}\right)(P<0.001)$. No difference was observed between the median indoor $\left(40 \mu \mathrm{g} / \mathrm{m}^{3}\right.$; range $\left.21-58 \mu \mathrm{g} / \mathrm{m}^{3}\right)$ and outdoor $\mathrm{PM}_{2.5}$ levels $\left(35 \mu \mathrm{g} / \mathrm{m}^{3}\right.$; range $\left.22-54 \mu \mathrm{g} / \mathrm{m}^{3}\right)$ of the non-smoking venues $(P=0.917)$ (Figure 1).

Waterpipe smoking was observed in 10 venues and cigarette smoking was observed in 17 venues. Nine of the venues included both types of smoking.
An overall mean of 1.3 cigarette smokers (range $0-4.3$ ) and 7.0 waterpipe smokers (range 0-13.7) were observed in smoking venues. The mean internal volume of the smoking venues (477 $\mathrm{m}^{3}$ ) was nearly double that of the nonsmoking venues $\left(247 \mathrm{~m}^{3}\right)$. The active smoker density for smoking venues ranged from 0.2 to $6.5 / 100 \mathrm{~m}^{3}$ and was found to be positively correlated with indoor $\mathrm{PM}_{2.5}$ levels (Spearman $r=0.56$; $P=0.006$ ).

\section{Discussion}

$\mathrm{PM}_{2.5}$ levels were found to be nearly 3 times higher inside venues with smoking compared to levels outside of these venues, and also significantly higher than levels in non-smoking venues in
Gaza city. The present data indicate that SHS is a major indoor air pollutant in Gaza city and highlights the need to implement policies protecting employees and the public from SHS exposure. Furthermore, these data are consistent with measurements taken from indoor public venues in other EMR countries. For example, high $\mathrm{PM}_{25}$ levels have been found in indoor public venues with observed smoking in Syria $\left(372 \mu \mathrm{g} / \mathrm{m}^{3}\right)$, Tunisia (328 $\left.\mu \mathrm{g} / \mathrm{m}^{3}\right)$ and Lebanon $\left(342 \mu \mathrm{g} / \mathrm{m}^{3}\right)$ [13-15].

The World Health Organization (WHO) has established air quality guidelines to help inform policy-makers on appropriate air quality targets to reduce disease and premature death caused by exposure to air pollution. To 


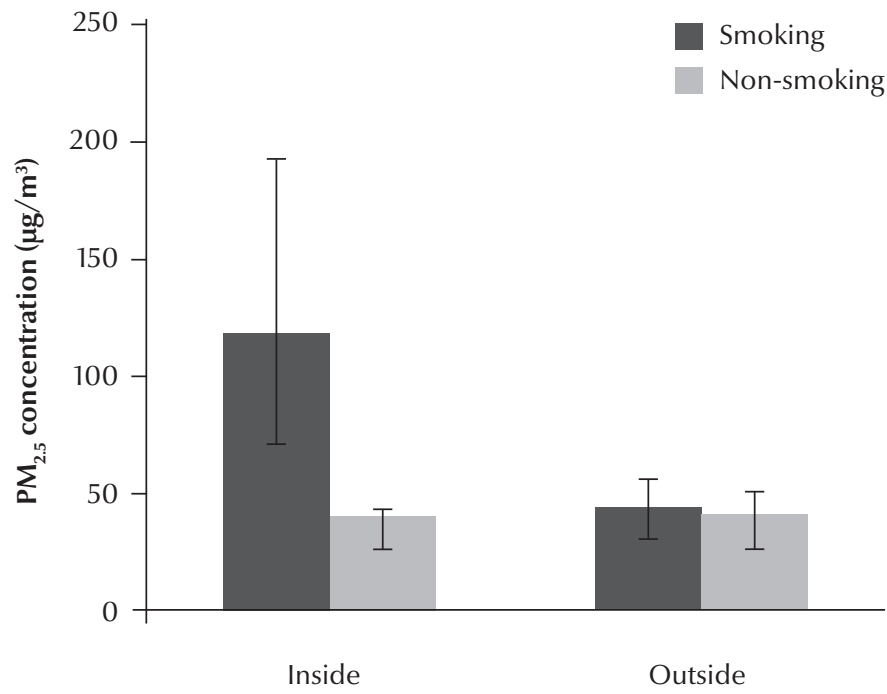

Figure 1 Median and interquartile range of levels of fine particulate matter $\leq 2.5 \mu \mathrm{m}$ $\left(\mathrm{PM}_{2.5}\right)$ inside and outside smoking $(n=18)$ and non-smoking $(n=5)$ venues in Gaza city

help provide a context for the indoor particulate levels measured within this study, a comparison can be made to the WHO's guideline for $\mathrm{PM}_{25}$. The WHO 24-hour mean $\mathrm{PM}_{2.5}$ guideline is $25 \mathrm{\mu g} /$ $\mathrm{m}^{3}[16]$. The median $\mathrm{PM}_{2.5}$ level forvenues with observed smoking in our study was $117 \mu \mathrm{g} / \mathrm{m}^{3}$, or more than 4 -fold the WHO guideline. Therefore, employees and patrons inside these venues are at risk of being exposed to particulate pollution levels that are regarded as unsafe. It is noted that in Gaza city, the median ambient concentrations of $\mathrm{PM}_{2.5}$ ( 42 $\mu \mathrm{g} / \mathrm{m}^{3}$ for all venues) were also found to exceed the WHO guideline for $\mathrm{PM}_{2.5}$, as was the concentration inside nonsmoking venues $\left(40 \mu \mathrm{g} / \mathrm{m}^{3}\right)$, but much less so than indoor levels in venues where smoking was observed. Outdoor sources may be contributing to these elevated ambient and indoor levels, including emissions from automobiles and power plants.

Comprehensive smoke-free policies results in dramatic reductions in indoor particulate pollution. Studies conducted in the United States, Scotland and Italy reported reductions in indoor $\mathrm{PM}_{2.5}$ levels of $95 \%, 86 \%$ and $64 \%$, respectively, after indoor smoking was banned [17-19]. These policies have also been found to lead to immediate improved health outcomes among venue employees as well as the general public. For example, reported respiratory symptoms and irritation significantly improved among a sample of hospitality workers in the United States after the implementation of a local smoke-free policy [20]. In addition, reports from several jurisdictions have found significant declines in hospital visits for acute myocardial infarction after implementation of smoke-free legislation [21]. Smoke-free policies have also been shown to be associated with increased smoking cessation and a reduction in youth smoking $[22,23]$.

Several limitations should be considered when interpreting these data. Data were collected during the warm summer months, a time when many businesses open windows or make other accommodations which may have impacted air exchange rates. Conducting measurements at a different time of year may lead to different particulate concentrations indoors. In addition, a small, convenience sample was employed. Therefore, these results may not be representative of all public venues in Gaza city. However, the levels measured are consistent with monitoring conducting in many other jurisdictions around the world which have not banned indoor smoking [13-15]. Finally, smoking may not have been the only source of indoor particulate pollution. Other contributors, such as cooking, may have influenced $\mathrm{PM}_{25}$ measurement. However, evidence shows that smoking, and not cooking emissions, is the overwhelming source of indoor $\mathrm{PM}_{25}[17-19]$.

\section{Conclusion}

In this first known study to measure SHS emissions in public places in the Palestinian Authority, smoking inside public places was found to contribute to unsafe levels of indoor air quality. Article 44 of the Palestinian Legislative Council public health law states that, "The ministry should take the suitable measures to limit the harm created by the spread of smoking" [24]. Comprehensive smoke-free policies offer full protection to non-smoking adults and children from the dangers of SHS exposure and have been shown to improve health and wellbeing of populations. A comprehensive smoke-free policy is needed in Gaza city to help reduce exposure to SHS, a major cause of preventable disease and premature death

\section{Acknowledgements}

Logistical support was provided by Framework Convention Alliance and Dr Georges Saade of the Faculty of Public Health at Lebanese University. The authors would also like to thank Abedallah Al Hamadani for assistance with data collection.

Funding: This research was funded by Action on Smoking and Health International.

Competing interests: None declared. 


\section{References}

1. The health consequences of involuntary exposure to tobacco smoke: a report of the Surgeon General. Atlanta, GA: US Department of Health and Human Services, Centers for Disease Control and Prevention, Coordinating Center for Health Promotion, 2006.

2. 11th report on carcinogens. Research Triangle Park, North Carolina, US Department of Health and Human Services, National Toxicology Program, 2005.

3. Koh HK et al. Understanding worldwide youth attitudes towards smoke-free policies: an analysis of the Global Youth Tobacco Survey. Tobacco Control, 2011, 20:219-225.

4. Oberg M et al. Worldwide burden of disease from exposure to second-hand smoke: a retrospective analysis of data from 192 countries. Lancet, 2011, 377:139-146.

5. Abusalah A et al. Low birth weight and prenatal exposure to indoor pollution from tobacco smoke and wood fuel smoke: a matched case-control study in Gaza Strip. Maternal and Child Health Journal, 2012, 16(8):1718-1727.

6. Abugamer M, Coomans D, Louckx F. Health behavior and health awareness in infant mortality in the Gaza Strip. European Journal of Public Health, 2012, 22(4):539-544.

7. Towards a strategy for cancer prevention and control in the Eastern Mediterranean Region. Cairo, World Health Organization, Regional Office for the Eastern Mediterranean, 2009 (WHO$\mathrm{EM} / \mathrm{NCD} / 060 / \mathrm{E})$.

8. Syria bans smoking in public places. Reuters, 12 Oct 2009 (http://in.reuters.com/article/2009/10/11/us-syria-smokingban-idINTRE59A22P20091011, accessed 2 March 2013).

9. The Public Health Law No. 47. Chapter XII, Article 53. Amman, Hashemite Kingdom of Jordan, 2008.

10. Lebanon bans smoking in public places. The Daily Star, Lebanon, 17 August 2011 (http://www.dailystar.com.lb/News/Politics/2011/Aug-17/New-law-bans-smoking-in-public-places. ashx\#axzzlffyPLoZJ, accessed 2 March 2013).

11. Haddad LG et al. Secondhand smoking in Jordan: Clearing the air for one of the highest tobacco prevalence countries in the Middle East. Tobacco Use Insights, 2011, 4:107.

12. Tobacco free air. Training and resources for a smokefree world. Roswell Park Cancer Institute [website] (http://tobaccofreeair.org/index.php, accessed 2 March 2013).
13. Hyland A et al. A 32-country comparison of tobacco smoke derived particle levels in indoor public places. Tobacco Control, 2008, 17:159-165.

14. Connolly GN et al. How smoke-free laws improve air quality: a global study of Irish pubs. Nicotine \& Tobacco Research, 2009, 11:600-605.

15. Saade G et al. Indoor secondhand tobacco smoke emission levels in six Lebanese cities. Tobacco Control, 2010, 19:138-142.

16. Air quality guidelines. Global update 2005. Particulate matter, ozone, nitrogen dioxide, and sulphur dioxide. Geneva, World Health Organization, 2005.

17. Repace JL, Hyde JN, Brugge D. Air pollution in Boston bars before and after a smoking ban. BMC Public Health, 2006, 6:266.

18. Semple $S$ et al. Secondhand smoke levels in Scottish pubs: the effect of smoke-free legislation. Tobacco Control, 2007, 16:127-132.

19. Valente $\mathbf{P}$ et al. Exposure to fine and ultrafine particles from secondhand smoke in public places before and after the smoking ban, Italy 2005. Tobacco Control, 2007, 16:312-317.

20. Eisner MD, Smith AK, Blanc PD. Bartender's respiratory health after establishment of smokefree bars and taverns. Journal of the American Medical Association, 1998, 280:1909-1914.

21. Glantz SA. Meta-analysis of the effects of smokefree laws on acute myocardial infarction: an update. Preventive Medicine, 2008, 47:452-453.

22. Hahn EJ. Smokefree legislation: a review of health and economic outcomes research. American Journal of Preventive Medicine, 2010, 39:S66-S76.

23. Siegel $\mathrm{M}$ et al. Local restaurant smoking regulations and the adolescent initiation process: results of a multilevel contextual analysis among Massachusetts youth. Archives of Pediatrics and Adolescent Medicine, 2008, 162:477-483.

24. Public Health Law No. (20) for the year 2004 AD. Palestinian Legislative Council (www.hdip.org/public\%20health\%20law\%20 English.pdf, accessed 2 March 2013). 